\title{
STRATEGI PERMODALAN PEDANGAN PASAR SOPONYONO DI KECAMATAN RUNGKUT KOTA SURABAYA
}

Eka Fajarwati

Program Studi Manajemen - Fakultas Ekonomi dan Bisnis

Universitas Muhammadiyah Gresik

\begin{abstract}
The market is generally divided into two, namely traditional markets and modern markets. Traditional market is a market that has a simple buying and selling activities, there is a bargain with a means of payment in the form of cash. In addition, the market is not only a place for the community in meeting the daily needs, but also the center of the community's economic drive. Traditional market is an important channel in the distribution process of agribusiness products as big as food product of daily necessities. The competition of traditional markets and modern markets is getting tighter. The government is trying to assist the development of traditional markets in order to compete with modern markets by planning the revitalization and fostering of market management so that not only physical improvements are made but also services and market management mangement. Related to this problem is capital strategy applied by traditional market trader Soponyono in face of tight competition with modern market. This research method is descriptive study by using qualitative approach. Data collection techniques through (1) indepth interview, in-depth interviews until the data obtained is considered sufficient and (2) observation that is observing the learning process undertaken. The process of data analysis using capital strategy theory. The selection of this theory is based on the object of research that is Soponyono Surabaya Market so that it can know more deeply about the capital process of Soponyono market traders related to the problem of competition with modern market Based on the result of research known that capital strategy of traditional traders in facing modern market through banking funding, Private capital and BKM and BMT. Obstacles from the cooperation of management of Taman Remaja Surabaya by City Government
\end{abstract}

Keywords: Capital Strategy, Traditional Market and Modern Market

\section{PENDAHULUAN}

Menurut Herman (2011), pasar dijelaskan sebagai kumpulan para penjual dan pembeli yang saling berinteraksi, saling tarik-menarik kemudian menciptakan harga barang di pasar. Pasar pada umumnya dibedakan menjadi dua, yaitu pasar tradisional dan pasar modern. Pasar tradisional merupakan pasar yang memiliki aktivitas jual beli yang sederhana, terjadi tawar menawar dengan alat pembayaran berupa uang tunai. Selain itu, pasar tidak hanya menjadi tempat bagi masyarakat dalam memenuhi kebutuhan seharihari, melainkan juga pusat penggerak perekonomian masyarakat. Pasar tradisional merupakan saluran penting dalam proses distribusi produk-produk agribisnis yang sebagai besar merupakan produk pangan kebutuhan sehari-hari. Beragam produk pangan yang 
dikonsumsi setiap hari oleh masyarakat sebagian besar beredar dan terdistribusi melalui sistem perdagangan yang terjadi di pasar tradisional. Seiring dengan perkembangan zaman, dengan gaya dan standart hidup masyarakat yang semakin meningkat menuntut segala sesuatu yang lebih baik tidak sekedar membeli produk, namun faktor kenyamanan juga menjadi sesuatu yang diharapkan dapat menjadi daya tarik pasar tradisional.

AC Nielsen (2010) menyatakan bahwa 29\% masyarakat tetap menyukai berbelanja dipasar tradisional. Bedasarkan penelitian ini, meskipun pasar tradisional identik dengan kesan jorok, kumuh, penggap, bau dan becek, pasar tradisional masih menjadi tempat favorit bagi sebagian masyarakat untuk berbelanja. Asosiasi Pedagang Pasar Selurh indonesia (APPSI) menyatakan bahwa hal penting yang harus dilakukan untuk menjamin keberadaan pasar tradisional adalah dengan memperbaiki infrastuktur pasar tradisional, penataan ulang para Pedagang Kaki Lima (PKL), dan penciptaan praktik pengelolaan pasar yang lebih baik.

Kebanyakan para pedagang secara terbuka mengatakan kenyakinan mereka bila persyaratan diatas terpenuhi (Harmanto, 2007). Bagi sebagian masyarakat berbelanja dipasar tradisional menjadi pilihan dengan alasan harga yang lebih terjangkau, bisa melakukan tawarmenawar harga dan pengelaman berbelanja dipasar tradisional menjadi pilihan dengan alasan harga yang lebih terjangkau, bisa melakukan tawar-menawar harga dan pengalaman berbelanja dengan interaksi sosial yang tidak ada jika dilakukan di pasar modern. Pasar tradisional masih memiliki porsi yang cukup besar dalam memenuhi kebutuhan masyarakat.

Pasar Tradisional dibangun dan dikelola oleh Pemerintah, Pemerintah Daerah, Swasta, Badan Usaha Milik Negara dan Badan Usaha Milik Daerah termasuk kerjasama dengan swasta, dengan tempat usaha berupa toko, kios dan tenda yang dimiliki/dikelola oleh pedagang kecil, menengah, swadaya masyarakat atau koperasi dengan usaha skala kecil, modal kecil dan dengan proses jual beli barang dagangan melalui tawar-menawar. Pengertian diatas berdasarkan Perda Kota Surabaya No 8 Tahun 2014 tentang penataan dan pembinaan pasar tradisional. Surabaya sebagai salah satu kota besar di Indonesia telah melakukan berbagai revitalisasi pada pasar tradisional. Surabaya memiliki 81 pasar tradisional dimana pengelolaannya berada di PD Pasar Surya. Sejumlah $20 \%$ pasar tradisional telah direvitalisasi. Berdasarkan hasil wawancara Kepala Departemen Penelitian dan Pengembangan PD Pasar Surya menjelaskan bahwa revitalisasi pasar tradisional dilakukan sebab berdasarkan data APPSI (Asosiasi Pedagang Pasar Seluruh Indonesia) menjelaskan bahwa sejak tahun 2004 diketahui bahwa beberapa pasar di Surabaya ditutup akibat turunnya jumlah pembeli. Perkembangan pasar modern saat ini justru semakin berkembang di Surabaya dibandingkan jumlah pasar tradisional. Terdapat $65 \%$ sarana perbelanjaan di Surabaya didominasi ileh pasar modern baik berupa factory outlet, supermarket, minimarket, department store maupun mall (Kompas, 13/10/2010). 
Salah satu pasar retail baru yang didirikan yakni Transmart yang dibuka di daerah Rungkut dimana berdekatan dengan beberapa pasar tradisional serta minimarket. Pihak Dirjen Perdagangan Dalam Negeri serta pengurus pengelola Asparindo (Asosiasi Pengelola Pasar Indonesia) mengemukakan bahwa jarak antara pasar modern dan pasar tradisional diatur pada Perpres. Hal ini terkait dengan rencana tata ruang yang masih disusun bagi tiap kabupaten dan kota (beritajatim.com 8/10/2016). Hal ini menunjukkan bahwa persaingan pasar tradisional dan pasar modern semakin ketat. Pihak pemerintah berusaha membantu perkembangan pasar tradisional agar mampu bersaing dengan pasar modern dengan merencanakan adanya revitalisasi dan pembinaan pengelolaan pasar sehingga tidak hanya perbaikan fisik yang dilakukan namun juga pelayanan dan mangement pengelolaan pasar.

Objek pada penelitian ini yakni Pasar Soponyono dimana secara lokasi berdekatan dengan salah retail pasar modern terbesar yang sedang membuka pangsa pasar baru yakni Transmart Rungkut dengan berbagai fasilitas menarik yang disediakan. Kehadiran pasar modern diharapkan tidak mengganggu pangsa pasar tradisional khususnya Pasar Soponyono. Pasar tradisional dalam hal ini pasar Soponyono dinilai mampu bersaing dengan retail modern, walaupun kehadiran retail modern telah menggeser peranan pasar tradisional, kebijakankebijakan pemerintah daerah telah memberikan dukungan terhadap pasar tradisional. Pemerintah Kota Surabaya bekerjasama dengan berbagai pihak salah satunya
Asparindo tentang manajemen tata pasar secara nasional sehingga pengelolaan pasar tidak hanya berkaitan dengan kebersihan namun stabilitas harga. Peran kerjasama ini guna meningkatkan pengelolaan kesejahteraan pasar sekaligus menjaga keterjangkauan harga.

Berdasarkan latar belakang masalah yang disajikan diatas, maka penulis tertarik untuk melakukan penelitian pada strategi permodalan yang dilakukan di Kawasan Pasar Soponyono Kecamatan Rungkut Kota Surabaya. Selanjutnya penelitian ini diberi judul "Strategi Permodalan Pedagang Pasar Soponyono di Kecamatan Rungkut Kota Surabaya"

\section{Rumusan Masalah}

Berdasarkan latar belakang permasalahan, maka rumusan penelitiannya yang adalah Bagaimana Strategi Permodalan Pedagang Pasar Soponyono di Kecamatan Rungkut Kota Surabaya?

\section{Tujuan Penelitian}

Berdasarkan rumusan masalah, maka tujuan penelitian ini adalah untuk mengetahui Strategi Permodalan Pedagang Pasar Soponyono di Kecamatan Rungkut Kota Surabaya.

\section{LANDASAN \\ TEORI 2.2.1 Teori \\ Struktur Modal}

Salah satu teori struktur modal yakni Teori Ketidak-relevanan Struktur Modal (Modigliani dan Miller, 1958) atau yang lebih dikenal dengan teori MM. Teori ini menyatakan bahwa struktur modal tidak berpengaruh atau tidak relevan dalam menentukan nilai. Artinya, perubahan komposisi asset dan 
hutang tidak akan merubah struktur nilai menjadi lebih besar atau lebih kecil. Pembiayaan dengan hutang (leverage) tidak daapat menciptakan suatu penambahan nilai yang lebih besar dibandingkan dengan yang tidak mendominasi pola pembiayaan dengan hutang (leverage).

Teori MM ini sering disebut "teori statik stuktur modal". Kata statik mewakili pemahaman bahwa perubahan dalam komposisi struktur modal tidak akan mempengaruhi nilai. Keputusan leverage tidak akan memberikan dampak yang nyata pada nilai. Tapi penemuan MM didasari beberapa asumsi yang tidak realistis, yaitu adanya informasi yang merata dan dapat diakses tanpa biaya, tidak adanya biaya transaksi, tidak ada pajak, adanya tingkat bunga pinjaman dan meminjamkan yang sama yaitu tingkat bunga bebas resiko (risk free rate), EBIT tidak terpengaruh oleh penggunaan hutang.

Pada tahun 1963, MM melakukan penelitian lanjutan dengan menggunakan asumsi adanya pajak, MM mengemukakan bahwa usaha yang mempunyai hutang meningkat sebesar pajak yang ditabung (tax shield), dengan demikian menyatakan bahwa penggunaan hutang dari struktur modal dapat mempengaruhi nilai usaha tersebut.

Teori berikutnya adalah Model Trade Off Theory yang menggambarkan bahwa struktur modal optimal dapat ditentukan dengan menyeimbangkan keuntungan atas penggunaan hutang (tax shield benefit of leverage) dengan cost of financial distress dan agency cost. Teori tersebut merupakan pengembangan dari teori struktur modal MM, dimana salah satu asumsi yang digunakan oleh MM dalam teori struktur modalnya adalah tidak adanya biaya kebangkrutan (bankruptcy cost). Asumsi tersebut tentunya tidak realistis karena pada dunia nyata kebangkrutan dapat menimbulkan berbagai masalah atau biaya (Brigham dan Houston, 2006:33).

Berbagai cara dilakukan dalam rangka penghematan pajak atas hutang, tetapi juga mempertimbangkan adanya biaya kebangkrutan. Menurut teori tradeoff bahwa untuk menyeimbangkan antara manfaat pembiyaaan dengan menggunakan hutang dengan tingkat suku bunga yang tinggi dan biaya kebangkrutan. Menurut Brigham dan Enhardt (2001), struktur modal yang optimal merupakan keseimbangan antara penghematan pajak atas penggunaan dengan biaya kesulitan keuangan akibat penggunaan hutang, sebab biaya dan manfaat akan saling meniadakan satu sama lain (trade off). Apabila terjadi pergeseran tingkat financial leverage sampai melewati titik struktur modal optimal, maka besar biaya kebangkrutan akan melebihi manfaat pajak (Breally dan Myers,2000).

\subsubsection{Pasar}

Menurut Gilarso (2004 ; 154) pengertian pasar dalam arti sempit adalah suatu tempat dimana pada hari tertentu para penjual dan pembeli dapat bertemu untuk jual beli barang. Sedangkan pengertian pasar dipakai dalam arti yang lebih luas yaitu dimana pertemuan antara penjual dan pembeli untuk melaksanakan transaksi jual beli tidak lagi terbatas pada suatu tempat tertentu saja maupun pada hari tertentu. Pendat lain di kemukakan oleh Miller dan Meiners (2000 ; 23), 
yang mengatakan pasar dalam arti laus adalah suatu pasar tindakan harus suatu tempat, tapi suatu industri yang menjadi ajang operasi kekuatan-keukuatan yang menentukan harga, dengan kata lain dalam pasarlah pemasokan dan permintaan beroperasi.

\subsubsection{Pasar Tradisional}

Menurut Herman (2011) mengatakan bahwa Pasar Tradisional adalah pasar yang dikelola secara sederhana dengan bentuk fisik tradisional yang menerapkan sistem transaksi tawarmenawar secara langsung dimana fungsi utamanya adalah untuk melayani kebutuhan masyarakat baik didesa, kecamatan, dan lainnya. Harga yang berlaku di pasar tradisional ini mempunyai sifat yang tidak pasti, oleh karena itu bisa dilakukan tawar-menawar. Bila dilihat dari tingkat kenyamanan pasar tradisional selama ini cenderung kumuh dengan lokasi yang tidak tertata rapi. Pembeli di pasar tradisional (biasanya kaum ibu) mempunyai perilaku yang senang bertransaksi dengan berkomunikasi atau berdialog dalam hal penetapkan harga, mencari kualitas barang, memesan barang yang diinginkan, dan perkembangan harga-harga lainnya.

Barang yang dijual di pasar tradisional umumnya barang-barang lokal dan ditinjau dari segi kualitas dan kuantitas, barang yang dijual dipasar tradisional dapat terjadi tanpa melalu penyortiran yang kurang ketat. Aspek kuantitas, jumlah barang yang disediakan tidak terlalu banyak sehingga apabila ada barang yang dicari tidak ditemukan disatu kios tertentu, maka dapat dicari ke kios lain. Kendala yang dihadapi pada pasar tradisional diantaranya mengalami kesulitan dalam memenuhi kontinuitas barang, menjaga kualitas barang, lemah dalam penguasaan teknologi dan manajemen sehingga melemahkan daya saing.

Pasar tradisional biasanya dibangun dan dikelola oleh Pemerintah Daerah, Swasta, Badan Usaha Milik Negara dan Badan Usaha Milik Daerah, termasuk kerjasama swasta dengan tempat usaha berupa toko, kios, los, dan tenda yamg dimiliki atau dikelola oleh pedagang kecil, menengah, swadaya masyarakat atau koperasi dengan usaha skala kecil, modal kecil, dan dengan proses jual beli barang dagangan melalui tawarmenawar (Pepres RI No.112,2007). Beberapa Stokeholder yang berperan memiliki dan memajukan pasar tradisional dengan berupaya meningkatkan daya saing terhadap pasar modern.

Menurut Noor $(2013 ; 259)$, Organisasi apa pun sebagai bagian masyarakat, harus peka terhadap lingkungannya tersebut. Ada dua faktor yang menuntut adanya pengembangan organisasi yaitu faktor internal dan factor eksternal.

1. Lingkungan eksternal

Adalah segala keseluruhan faktor yang ada di luar organisasi yang dapat mempengaruhi organisasi dan kegiatan organisasi. Beberapa faktor tersebut, antara lain politik, hukum, kebudayaan, teknologi, sumberdaya alam, demografi, dan sebagainya. Adalah penyebab perubahan yang berasal dari luar, atau sering disebut lingkungan. Organisasi bersifat responsive terhadap perubahan yang terjadi di lingkungannya. Oleh karena itu, jarang sekali organisasi melakukan perubahan besar tanpa 
adanya dorongan yang kuat dari lingkungannya.

Artinya, perubahan yang besar itu terjadi karena lingkungan menuntut seperti itu. Beberapa penyebab perubahan organisasi yang termasuk faktor ekstern adalah perkembangan teknologi, faktor ekonomi, dan peraturan pemerintah.

2. Lingkungan Internal

Lingkungan internal adalah segala keseluruhan Lingkungan internal adalah segala keseluruhan faktor yang ada di dalam organisasi di mana faktor tersebut dapat mempengaruhi organisasi dan kegiatannya. Penyebab perubahan yang berasal dari dalam organisasi yang bersangkutan dapat berasal dari berbagai sumber. Misalnya, pengaruh kebijakan manajemen organisasi dan gaya, sistem dan prosedur, serta sikap karyawan. Perubahan organisasi dilakukan untuk mencocokkan dengan kebutuhan yang ada.

\subsubsection{Pasar Modern}

Selanjutnya Sinaga (2006) mengatakan bahwa pasar modern adalah pasar yang dikelola dengan manajemen modern, umumnya terdapat di kawasan perkotaan, sebagai penyedia barang dan jasa dengan mutu dan pelayanan yang baik kepada konsumen (umumnya anggota masyarakat kelas menengah ke atas). Pasar modern antara lain mall, supermarket, departement store, shopping centre, waralaba, toko mini swalayan, pasar serba ada, toko serba ada dan sebagainya. Barang yang dijual disini memiliki variasi jenis yang beragam. Selain menyediakan barang-barang lokal, pasar modern juga menyediakan barang impor.
Barang yang dijual mempunyai kualitas yang relatif lebih terjamin karena melalui penyeleksian terlebih dahulu secara ketat sehingga barang yang rijek/tidak memenuhi persyaratan klasifikasi akan ditolak. Secara kuantitas, pasar modern umumnya mempunyai persediaan barang di gudang yang terukur. Dari segi harga, pasar modern memiliki label harga yang pasti (tercantum harga sebelum dan setelah dikenakan pajak).

Faktor-Faktor Pasar Modern Persaingan Antara Pasar Tradisional dan Pasar Modern. Menurut Rahayu dan Fitanto (2010), menyatakan bahwa dengan kondisi yang terjadi di pasar jika banyak perusahaan menjual produk-produk yang serupa tapi tak sama hal ini termasuk ke dalam struktur pasar yang dikenal dengan persaingan monopolistik. Persaingan monopolistik menyerupai persaingan sempurna dalam tiga hal : terdapat banyak penjual dan pembeli, mudah keluar masuk industri, dan perusahaan-perusahaan menganggap harga perusahaan lain tetap.

Adapun perbedaan antar persaaingan sempurna dengan monopolistik adalah pada produknya. Jika pada persaingan sempurna produknya identik tetapi pada monopolistik produknya lebih didiferensiasikan. Diasumsikan jadi produk yang dijual tidak homogen akan tetapi sengaja dibedakan melalui berbagai macam program promosi penjualan sehingga meskipun barang yang diperdagangkan sebenarnya dapat saling menggantikan, konsumen mempunyai preferensi untuk memilih produk dari pasar tradisional maupun pasar modern. 


\subsubsection{Strategi}

Purwokerto (2016), menyatakan Strategi adalah cara yang ditempuh untuk mencapai tujuan berdasarkan analisa yang dilakukan terhadap faktor internal dan eksternal. Strategi berkaitan dengan tujuan akhir sedangkan taktik berkaitan dengan tujuan menengah. Pada organisasi bisnis atau perusahaan, strategi merupakan cara untuk mendapatkan keuntungan yang besar, sebaliknya dalam organisasi non bisnis atau organisasi non komersil strategi adalah cara untuk memuaskan anggotanya. Dalam organisasi di pemerintahan strategi merupakan cara untuk bisa memberi pelayanan yang maksimal kepada masyarakat sebagai pembayar pajak.

Menurut Sjafrizal (2008), Strategi adalah arah atau jalan yang akan ditempuh organisasi dalam rangka menjalankan misinya untuk menuju pencapaian visi. Menurut Kamus Besar Bahasa Indonesia (KBBI), strategi adalah ilmu dan seni menggunakan semua sumber daya untuk melaksanakan kebijaksanaan-kebijaksanaan tertentu dalam perang maupun damai.

Secara eksplisit, strategi adalah rencana tindakan yang menjabarkan alokasi sumber daya dan aktivitas lain untuk menanggapi lingkungan dan membantu organisasi mencapai sasaran. Sedangkan menurut Armstrong (1996), merumuskan strategi adalah mengenai penetapan tujuan (tujuan strategi) dan mengalokasikan/ menyesuaikan sumber daya dengan peluang (strategi berbasis sumber daya) sehingga dapat mencapai kesesuaian yang efektif dan penerapan strategi tergantung pada kapabilitas strategi organisasi yang akan memasukkan kemampuan, tidak hanya untuk memformulasikan tujuan strategi tapi juga untuk mengembangkan dan menerapkan rencana strategi melalui proses manajemen strategi. Intinya, strategi adalah pilihan untuk melakukan aktivitas yang berbeda atau untuk melaksanakn aktivitas dengan cara berbeda dari pesaing.

\subsubsection{Permodalan}

Modal merupakan hal yang utama dalam menjalankan suatu usaha, termasuk berdagang. Modal adalah semua bentuk kekayaan yang digunakan dalam proses produksi atau menghasilkan output. Modal merupakan kekayaan dapat menghasilkan keuntungan pada waktu yang akan datang. Modal yang digunakan dapat bersumber dari modal sendiri, namun bila ternyata modal sendiri tidak mencukupi dapat ditambah dengan modal pinjaman. Jadi, secara umum jenis modal yang dapat diperoleh untuk memenuhi kebutuhan modalnya terdiri atas modal sendiri dan modal pinjaman. (Suyadi Prawirosentono, 2001: 118)

Menurut Munawir $(2007 ; 116)$ "modal merupakan dana yang dipergunakan untuk membiayai kegiatan operasi perusahaan seharihari”. Jumingan (2006;66), modal merupakan sejumlah dana yang telah dikerluarkan untuk membelanjai operasi perusahaan dari hari kehari.

\section{METODE PENELITIAN 3.1 Pendekatan Penelitian}

Metode penelitian kualitatif asosiatif menurut Sugiyono $(2014 ; 1)$ adalah metode penelitian yang digunakan untuk meneliti pada kondisi obyek yang alamiah (sebagai lawannya adalah eksperimen) dimana penelitian adalah sebagai instrumen kunci, teknik pengumpulan data dilakukan secara triangulasi 
(gabungan), analisis data generalisasi. Metode deskriptif adalah metode yang memusatkan perhatian pada masalah-masalah yang ada pada saat penelitian yang dilakukan serta menggambarkan fakta tentang masalah diselidiki sebagaimana adanya dan diiringi dengan interprestasi rasional.

$$
\text { Jenis penelitian yang }
$$

digunakan dalam penelitian ini yaitu penelitian deskriptif. Penelitian deskriptif pada penelitian ini untuk mengambarkan strategi permodalan pasar tradisional (Sugiyono, 2014:205). Teknik pengambilan sampel untuk responden dalam penelitian ini yakni menggunakan Snowball Sampling dimana teknik penentuan sampel dengan awal jumlah kecil kemudian menjadi besar. Awal penentuan jumlah sampel yakni 5 orang kemudian data lebih dilengkapi dengan menambah jumlah responden sebanyak mungkin untuk menambah kedalaman informasi data penelitian (Sugiyono, 2014:85).

\subsection{Lokasi Penelitian}

Responden dalam penelitian ini adalah para pedagang yang membuka kios di pasara tradisional kota babat. Sehingga lokasi penelitian dilakukan pada "Pasar Soponyono" di Jl.Rungkut Asri 1 No.2 Rungkut, Surabaya Jawa Timur.

\subsection{Teknik Pengambilan Data}

Pengambilan atau pengumpulan data adalah suatu proses data primer untuk keperluan dalam penelitian. Pengambilan data merupakan langkah penting dalam metode ilmiah karena pada umumnya data yang dikumpulkan harus valid. Pengambilan data yang digunakan dalam penelitian ini terdiri dari (Sugiyono, 2014:225):

Wawancara mendalam merupakan salah satu cara untuk mengumpulkan data pada studi kualitatif agar dapat memperoleh informasi mendalam terkait dengan persepsi, pendapat, kepercayaan dan sikap tentang hal-hal yang berkaitan dengan epidemologi. Berikut rangkaian kegiatan yang dilakukan pada saat melakukan wawancara mendalam.

\subsection{Unit Analisis}

Unit analisis merupakan objek yang dijadikan penelitian. Penelitian ini mengangkat objek tentang strategi permodalan pedagang pasar Soponyono di Surbaya. Unit analisis dalam hal ini terkait strategi modal yang dimaksud adalah pilihan sumber modal yang dipilih oleh para pedagang dalam menjalankan dan mempertahankan kelangsungan usahanya hal ini dikaitkan dengan teori Purwokerto (2016) yang menyebutkan bahwa strategi modal adalah cara yang ditempuh untuk mencapai tujuan berdasarkan analisis yang dilakukan terhadap faktor internal dan ekstern

\subsection{Teknik Analisis Data}

Setelah mengumpulkan data yang dibutuhkan dalam penelitian, langkah selanjutnya yang harus dilakukan adalah melakukan analisis terhadap data yang telah terkumpul. Analisis data merupakan proses mengatur urutan data, mengorganisasikannya ke dalam suatu pola, kategorisasi dan satuan uraian dasar.

Analisis data dilakukan untuk mengkaji dan mengolah data yang telah terkumpul agar memperoleh simpulan yang sesuai dengan tujuan 
penelitian Metode analisis data yang digunakan dalam penelitian ini adalah dengan teknik analisis data deskriptif kualitatif dengan Model Miles and Huberman (Sugiyono, 2014:246) :

1. Reduksi data; dilakukan dalam penelitian dengan merangkum catatan-catatan lapangan dengan memilah hal-hal pokok yang berhubungan dengan permasalahan dalam penelitian, selanjutnya rangkuman catatancatatan lapangan disusun secara sistematis agar gambaran dapat lebih tajam.

2. Penyajian data dilakukan dengan mengelompokkan data yang telah ditelaah dan direduksi sesuai dengan definisi variabel. Menguji keabsahan data dilakukan dengan teknik pemeriksaan keabsahan data yang memanfaatkan informan lain untuk melakukan crosscheck hasil data yang diperoleh seperti hasil wawancara berupa rekaman, foto dan isian pernyataan yang dicrosscheck dengan dokumen tertulis perusahaan yang diminta. Ketika kedua sumber data sudah dinyatakan benar dan sama maka data yang di crosscheck diny

3. atakan diuji keabsahannya. Penafsiran data dilakukan dengan menjawab rumusan masalah yang dilakukan dengan deskripsi analitik. Deskripsi analitik adalah rancangan yang dikembangkan dari kategorikategori yang telah ditemukan dan mencari hubungan yang disarankan atau yang muncul dari data.

3. Menarik kesimpulan dan verifikasi.

Kesimpulan dirumuskan berdasarkan pada rumusan masalah penelitian.

\section{PENYAJIAN DATA DAN PEMBAHASAN \\ Strategi Permodalan Informan memaparkan} bahwa tujuan dari pengelolaan Pasar Soponyono adalah untuk memajukan dan mengembangkan pasar agar pedagang puas dengan kegiatan perdagangan yang dilakukan di Soponyono dan terkait dengan kondisi pasar saat ini diketahui bahwa meskipun terdapat berbagai pasar modern yang muncul tidak berdampak secara signifikan pada penjualan pasar yang cenderung stabil. Pengaruh adanya pasar modern berdampak tiga bulan pada awal pembukaan Transmart kemudian pihak manajamen pasar Soponyono dengan para pedagang melakukan evaluasi serta perbaikan manajemen dimulai dari strategi penjualan, kebersihan fasilitas pasar serta kestabilan harga. Adapun hasil wawancara dengan beberapa informan adalah sebagai berikut:

1. Informan: Bapak Syam (Kepala Pasar)

Pertanyaan:"Mohon maaf pak, bisa dijelaskan sasaran dan tujuan pasar ini?"

Jawaban : "Sasaran dan Tujuannya untuk memajukan dan mengembangkan pasar. Selain itu, tujuan kita adalah supaya pedagang sendiri puas. Pasar ini terdiri dari berbagai produk yang dijual oleh pedagang dan hampir semua kebutuhan masyarakat tersedia di pasar Soponyono. 
Memenuhi berbagai kebutuhan masyarakat dan meningkatkan perekonomian

khususnya pedagang tradisional."

2. Informan: Bapak Ahmad Huda (Pedagang Sembako)

Pertanyaan:"bagaimana dampak pasar modern terhadap transaksi pasar soponyono sebagai pasar tradisional? Apakah berpengaruh pak pada nilai omzet penjualan?"

Jawaban : "waktu ramainya pembukaan transmart sama pasar modern lain agak booming kan ya jadi penasaran, tapi ga lama dan ga begitu terasa efeknya buat saya pribadi, soalnya langganan kita kan orang-orang usaha juga kayak penjual warung kecil-kecil jadi ya pasti tetep beli disini. Buat strategi penjualan kalo saya dimasalah harga mbak, gimana-gimana kan kita tetep bias lebih murah ya dibandingkan pasar tradisional dan itu yang saya jaga, ditambah pelayanan yang bagus juga".

3. Informan: $\mathrm{Bu}$ Suhalami (Pedagang Buah)

Pertanyaan: "bagaimana reaksi pembeli dengan adanya transmart? Apakah penjualan juga ikut berpengaruh dengan berkurangnya pembeli?"
Jawaban: "hanya penasaran saja mbak, tapi kan semua ada pangsa pasar sendiri ya, kita pasar tradisional kan menengah ke bawahjadi harga menyesuaikan dengan kemampuan pembeli begitu juga transmart kan pembeliannya menengah ke atas, yang beli dan belanja juga jauh-jauh kalau kita melayani masyarakat sekitar mbak, buat strategi penjualan saya selain focus pada satu produk saya mulai melakukan diversifikasi produk agar pembeli tidak bosan. Situasi perkembangan pasar tradisional seiring perkembangan pasar tradisional seiring perkembangan pasar modern dinilai stabil dan hanya memberikan dampak sesaat terhadap penjualan, strategi penjualan yang dilakukan oleh pedagang pasar dengan memberikan kestabilan harga, menjaga alur distribusi yang baik didukung pelayanan yang baik sesuai pangsa pasar pembeli masingmasing."

4. Informan: Bapak Hamid (pedagang sembako)

Pertanyaan : "bagaimana strategi pihak pengelola atau pedagang pasar melihat adanya pasar modern transmart? Dan bagaimana startegi 


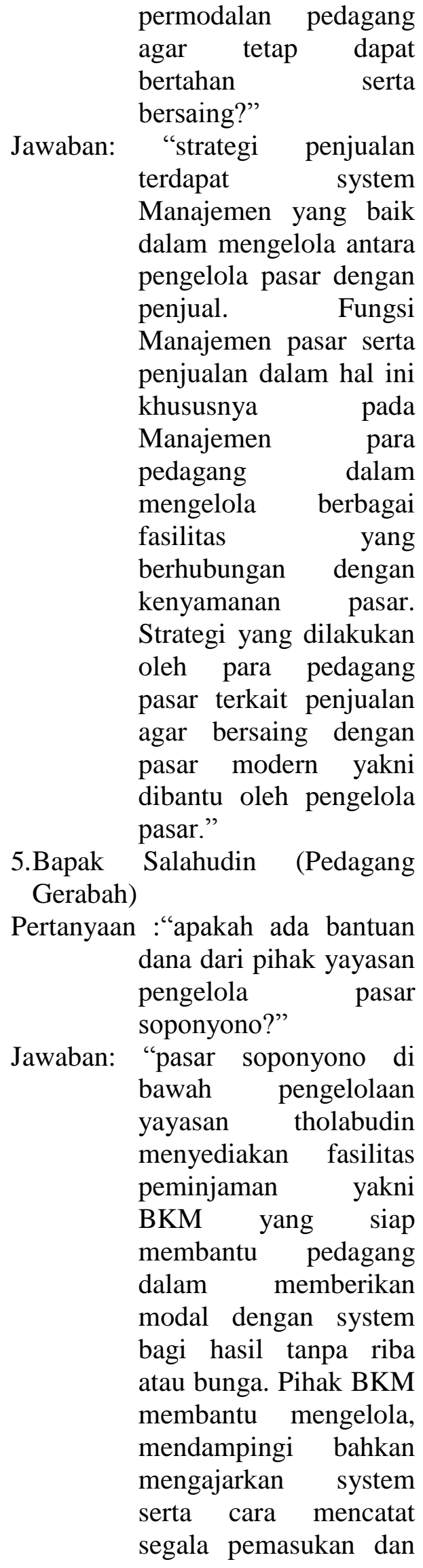

pengeluaran pedagang dengan baik kemudian menyerahkan kepada pihak pusat yayasan untuk dikaji dan dievaluasi sehingga diketahui bagaimana perkembangan

pedagang tersebut diikuti kemampuan membayar."

\section{Informan: Bapak Uwais \\ (Pedagang Gerabah)}

Pertanyaan :"kendala apa yang dialami oleh pedagang pasar untuk bertahan dan bersaing dengan pasar modern?"

Jawaban :"terdapat kendala dalam pengelolaan strategi modal para pedagang pasar soponyono. Kendala permodalan yang terjadi adalah pihak pedagang dinilai belum mampu memenuhi berbagai syarat untuk mengajukan pinjaman modal baik pada pihak bank maupun pengelola pasar BKM yayasan tholabuddin. Pedagang yang kesulitan mendapatkan pinjaman modal dinilai kurang memiliki inovasi dalam melakukan promosi pasar terutama untuk penjualan. Selain itu, kendala yang dialami dalam pengelolaan modal bagi para pedagang pasar tradisional adalah kurangnya dukungan dari pemerintah, dimana pemerintah hanya 
menuntut peran lebih dari pihak pengelola namun pada praktiknya para pedagang kurang mendukung terhadap tujuan dan program pasar sendiri serta pedagang bersikap acuh dan hanya focus pada kegiatan jual beli yang dilakukan atau dapat dikatakan asalkan mendapatkan uang dari kegiatan perdagangan di pasar."

7.Bapak Absobil (Pedagang Ikan) Pertanyaan :'bagaimana pihak pengelola dan Manajemen pasar berperan dalam mengatasi kendala pedagang tradisional?"

Jawaban :"kendala yang dialami oleh pihak pedagang soponyono dalam memperoleh sumber permodalan adalah kurang dalam melakukan promosi sehingga dagangan dinilai sepi membeli sehingga pihak kreditur baik bank maupun BKM yayasan tholabuddin masih belum bisa membantu masalah modal karena kekurangan dana atau uanng serta kurangnya dukungan dari para pedagang, di mana para pedagang hanya menuntut peran lebih dari pihak pengelola namun pada praktiknya para pedagang kurang mendukung terhadap tujuan dan program pasar sendiri serta pedagang bersikap acuh dan hanya focus pada kegiatan jual beli yang dilakukan atau dapat dikatakan asalkan mendapatkan uang dari kegiatan perdagangan di pasar."
8.Informan: $\mathrm{Bu}$ Rokayyah (Pedagang Ikan)
Pertanyaan :'bagaimana
persaingan antar pedagang tradisional di pasar dan strategi modal pedagang baru seperti apa?

Jawaban :"persaingan antar pedagang tradisional cukup ketat sehingga khusus pedagang baru memang mengalami tantangan tersendiri sehingga dibutuhkan modal lebih untuk bertahan dan berkembang.Sedangkan pihak pengelola pasar soponyono tetap melakukan penarikan retribusi pasar secara rutin kepada para pedagang atau pemilik stand yang ada meskipun stand tersebut jarang dibuka atau jarang beroperasi dalam kegiatan perdagangan. Apabila pedagang atau pemilik melakukan penunggakan dalam pembayaran dalam retribusi pasar, maka pihak pengelola melakukan tindakan lebih dengan mengenakan denda atau 
memutus saluran listrik yang ada."

9. Informan :Bu Ningsih (Penjual ayam)

Pertanyaan :"bagaimana strategi permodalan pedagang besar di pasar tradisional soponyono?"

Jawaban :"strategi penerapan permodalan para pedagang besar ini hamper sama dengan yang lain namun dalam skala yang lebih besar disesuaikan dengan omset dan operasional penjualan. Langkah yang diambil oleh pihak pedagang besar dalam mengelola sumber modal yakni dengan membedakan sumber modal tersebut Antara hutang bank dengan perhitungan bunga yang telah ditentukan, pinjaman koperasi atau BKM dan hasil keuntungan produksi yang kemudian disisihkan untuk modal kembali dalam berproduksi"

10. Informan :Pak Edi (penjual kelapa)

Pertanyaan :"bagaimana strategi permodalan pada usaha bidang kuliner dan percetakan kertas?"

Jawaban :"langkah yang diambil oleh pihak pedagang pasar dalam menglola sumber modal yakni dengan membedakan sumber modal tersebut Antara hutang bank dengan perhitungan bunga yang telah ditentukan, pinjaman koperasi atau BKM dan hasil keuntungan produksi yang kemudian disisihkan untuk untuk modal kembali dalam berproduksi"

11. Informan : $\mathrm{Bu}$ Dian dan Pak Soleh (Penjual Kue/ Penggiling daging)

Pertanyaan :"apa harapan bapak/ibu terkait peran Manajemen pasar dalam membantu perdagangan mengenai strategi permodalan?"

Jawaban :"langkah yang diambil oleh pihak pedagang pasar dalam mengelola sumber modal yakni dengan membedakan sumber modal tersebut Antara pedagang skala besar dan lama di pasar soponyono memiliki strategi dan persepsi yang berbeda dalam pengelolaan.

Manajemen strategi modal dalam mengembangkan usaha agar dapat bersaing dengan pasar modern. Berbagai model strategi pengelolaan modal berasal dari bermacammacam sumber yakni modal sendiri, perbankan, lembaga keuangan, koperasi, BKM yayasan tholabuddin dan BMT syariah. BKM yang dimiliki dapat lebih berperan aktif membantu para pedagang yang 


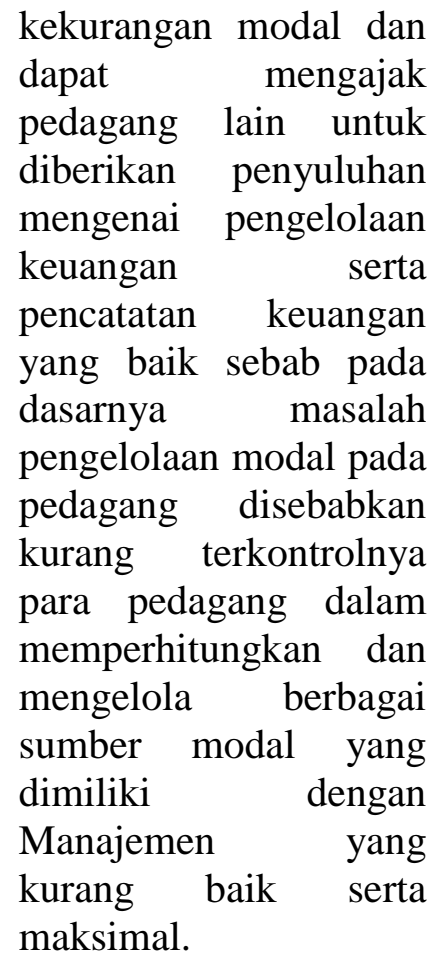

BAB V SIMPULAN DAN SARAN

Berdasarkan hasil temuan data yang diperoleh di lapangan serta hasil temuan literatur yang disajikan serta diinterpretasikan pada bab 4 maka pada bab ini dijelaskan mengenai kesimpulan hasil penelitian. Bab ini turut memberikan rekomendasi serta saran yang dirumuskan guna memberikan manfaat bagi terwujudnya pola sistem strategi permodalan yang dapat dilakukan oleh pedagang tradisional agar mampu bersaing dengan pasar modern.

\subsection{Kesimpulan}

Berdasarkan hasil wawancara dengan beberapa pedagang pasar maka dapat disimpulkan bahwa pedagang pasar Soponyono mengaplikasikan berbagai strategi yang ditempuh dalam mendapatkan modal yakni dengan mengandalkan modal sendiri dari hasil penjualan dan modal dari luar yakni pinjaman pada Bank, BMT Syariah, Koperasi
Simpan Pinjam dan BKM Tholabuddin. Alasan yang mendasari pedagang pasar untuk memilih strategi modal dari masing-masing sumber tersebut diketahui berdasarkan pertimbangan skala usaha, kebutuhan dana, kemampuan pembayaran dan persepsi mengenai pengelolaan modal yang berbeda.

$\begin{array}{ll}\text { Pedagang yang memilih } & \begin{array}{r}\text { mang } \\ \text { perbankan strategi }\end{array}\end{array}$

permodalan mayoritas karna jumlah modal yang diperoleh cukup besar, cepat dan pada umumnya pedagang dengan tipe skala besar memilih strategi ini. Khusus pedagang kelas menengah memilih mengandalkan modal sendiri hasil keuntungan penjualan atau menggunakan fasilitas BKM Tholabuddin sebagai sumber modal mayoritas dengan sistem bagi hasil yang cukup ringan sehingga mampu membantu operasional usaha. Pedagang yang baru merintis dan berkembang memilih untuk menggunakan modal pribadi dari hasil penjualan usaha maupun dari hasil penjualan aset sehingga mampu digunakan untuk mengembangkan usaha.

\subsection{Rekomendasi}

Peningkatan pelaksanaan kerja sama antara pihak pengelola pasar dan pedagang terkait kerjasama modal lebih dikembangkan. Berbagai bentuk sistem kerjasama atau kemitraan yang dilakukan diperlukan untuk membantu keterbatasan pedagang.

Peningkatan sarana dan
prasarana yang ada di pasar Soponyono guna menarik minat pembeli dan pelanggan sehingga arus perputaran transaksi pembelian berjalan lancar. Pengembangan manajemen profesional, sarana permainan serta berbagai inovasi ide 
baru turut diciptakan dan dikembangkan oleh pengelola untuk menarik minat warga terjadi peningkatan pendapatan.

Penelitian selanjutnya masih terdapat aspek lain yang dapat dikaji lebih mendalam sebab hal yang dibahas dalam penelitian ini mengenai strategi permodalan para pedagang pasar tradisional Soponyono dalam menghadapi persaiangan dengan pasar modern. Penelitian selanjutnya dapat membahas tema yang sama melalui pandangan pespektif lain misal dari segi ekonomi, sosial dan budaya. Perspektif lain dalam mengkaji sebuah penelitian ditujukan untuk memperkaya wawasan serta khasanah ilmu pengetahuan yang dapat dijadikan pedoman maupun acuan ketika lapangan mengalami masalah yang sama.

\section{DAFTAR PUSTAKA}

AC Nielsen.2010.The Digital Media and habits Attitudes of South East Asian Consumers.

Amstrong.1996.Dasar-Dasar Pemasaran. Jakarta:Intermedia Brealley,A.Richard and Myers,S.C. 2000. Principles of Corporate Finance. International Edition.Mc Grow Hill.

Brigham, F.Eugene and Ehrhardt,C.

Michael.2001.

Financial Management. Tenth Edition. Harcourt.

Brigham,F. Eugene and Joel F.Housten. 2006. Dasar-dasar Manajemen Keuangan. Terjemahan oleh Ali Akbar Yulianto. Jakarta: Salemba Empat.
Gilarso.2004.Pengantar Ilmu Ekonomi Makro. Yogyakarta :Kanisius

Harmanto.2007.Pasar Tradisional Kita Semakin Babak Belur

Herman, M. 2011. Selamatkan Pasar Tradisional. Jakarta: Gramedia Pustaka

Indrawati dan Indri. 2014.Analisis Sumber Modal Pedagang Pasar Tradisional DI Kota Pekanbaru.Jurnal Ekonomi Vol 22 No 1

Jumingan. 2006. Analisa Laporan Keuangan.Jakarta:Bumi Aksara

Miller dan Meiners. 2000. Teori Mikro ekonomi Intermediate. Jakarta: PT Raja Grafindo Persada

Munawir. 2007. Analisis Laporan Keuangan. Yogyakarta:Liberty

Navis, Mar'atus. 2015. Preferensi Pedagang Pasar Tradisional Terhadap Sumber Permodalan (Studo Pada Pedagang Pasar Merjosari, kecamatan Lowokwaru-Kota Malang). Skripsi FEB Universitas Brawijaya Malang.

Noor, Avy. 2013. Management Event. Bandung: Alfabeta

Noviono dan Manzilati. 2013.Pasar Tradisional Versus Pasar Modern :Studi Kasus Terhadap Kebijakan Pengelolaan Pasar di Kota Yogyakarta.

Peraturan Presiden RI No.112 Tahun 2007 Tentang Penataan dan Pembinaan Pasar Tradisional, Pusat Perbelanjaan dan Toko Modern Purwokerto. 2016. Strategi Pengembangan Pasar Tradisional Dalam Meningkatkan Kepuasan Pelanggan (Studi Kasus di Pasar Kliwon Karanglewas Banyumas Jawa Tengah). Skripsi IAIN Purwokerto. 
Rahayu dan Fitanto. 2010. Strategi Pedagang Pasar Tradisional Menghadapi Persaingan dengan Retail Modern dan Preferensi Konsumen (Studi Kasus Pada Pasar Legi Kota Blitar).

Sinaga. 2006. Makalah Pasar Modern vs Pasar Tradisional. Kementrian Koperasi dan UKM. Jakarta

Sjafrizal.2008.Ekonomi Regional, Teori dan Aplikasi. Padang: Baduose Media.

Sugiyono. 2014. Metode Penelitian Bisnis. CV Alfabeta:Bandung.

Suyadi Prawirosentono. 2001. Manajemen Operasi. Jakarta: Bumi Aksara 